\title{
Editorial
}

\section{Novo século da Revista de Medicina, o que muda?}

Tudo, começando pela nova política editorial. O ano de 2015, com certeza, foi um ano memorável para a Revista de Medicina, marcado por diversas conquistas. Marcas alcançadas pelo empenho e apoio de toda a equipe discente da Revista e do Conselho Consultivo com o grande apoio da Diretoria da Faculdade de Medicina da Universidade de São Paulo (FMUSP).

Continuamos líderes em acessos no Portal de Revistas USP, maior da América Latina. Tais resultados refletem a satisfação dos nossos leitores e, com certeza, brindam nossos trabalhos.

Fundamos o Núcleo Editorial de Revistas da FMUSP juntamente com a Revista de Terapia Ocupacional da USP e a revista Fisioterapia e Pesquisa. O órgão tem sede em uma sala própria no Prédio da Administração do HC-FMUSP preparada com tecnologia e equipamentos adequados para a editoração científica.

Em 2015, abrimos o sistema de submissão online, pelo Portal USP. O sistema permitiu melhor organização e otimização em nosso fluxo de artigos. Agora tudo é feito online. Mais que eficiência, a segurança é um ponto a ser observado. Tudo fica registrado no sistema.

A renovação do Conselho Consultivo foi também alvo de trabalho dessa gestão. Preocupamo-nos em expandi-lo convidando professores não apenas da Casa de Arnaldo, mas de outras universidades renomadas, inclusive internacionais.

Ademais, firmamos uma parceria com a disciplina de Telemedicina do Departamento de Patologia a fim de moldar um site interativo para o futuro. Ainda nesse ano, reativamos nossos perfis nas redes sociais e temos postado regularmente publicações sobre artigos selecionados. Tal iniciativa vai ao encontro com a era digital em que vivemos. Há necessidade de constante mudança e aprimoramento. Atitude que agora é critério obrigatório para indexação em outras bases de dados, nosso objetivo num horizonte próximo.

Com relação ao ensino, a Optativa “Abordagem Prática da Escrita Científica” foi aprimorada. Visamos ensinar aos alunos a produção de um artigo de revisão sistemática, em inglês. Disponibilizamos, agora, aulas online pelo sistema Med USP Digital e contamos com a participação de tutores de diversos departamentos. A disciplina, com três anos de existência, foi ministrada a cerca de 30 alunos e já resultou em 6 artigos produzidos aptos para publicação.

Almejamos, como já mencionei, conquistar mais indexações. Em 2015 entramos para a base de dados LATAM. Para isso, estamos fortalecendo nosso fluxo, política editorial, internacionalização e troca de experiências com outros periódicos brasileiros.

Outrossim, devido à complexidade de funções que a Revista tem adquirido, a criação de um Regimento Interno tornou-se necessária. Aprovamos, junto ao Departamento Científico da Faculdade de Medicina da USP (DC), tal documento que estrutura uma nova Estrutura Organizacional e firma uma política editorial forte e de qualidade. Tal proposta formalizou os cargos de Editor-Chefe; Editor-Executivo; Editores Associados; Editores Sêniors; Coordenadores de Mídias Digitais, Edições e da Optativa de Escrita Científica; Secretário Financeiro e Secretária Executiva.

Finalmente, estamos preparando uma série de 3 edições especiais para comemorar o Centenário de criação desse periódico científico. Solicitamos artigos de todos os Departamentos da FMUSP e de Universidades Internacionais renomadas. Os volumes serão totalmente em inglês e teremos uma cerimônia de lançamento no ano que vem. Fica aqui meu convite adiantado. Renovaremos, ainda, a partir da edição do centenário, toda a imagem da Revista. Em parceria com a Escola de Educação Permanente do HCFMUSP e com o suporte do Departamento de Informática do DC, elaboramos uma nova capa e logo comemorativo. 
Ex nihilo nihil fit. Nada vem do Nada. Parmênides usou essa frase referindo-se a origem do Universo. Eu, aqui, uso-a para reiterar meu agradecimento a todo trabalho da equipe que resultou em ótimos resultados. A todos os revisores, membros do Conselho Consultivo, aos professores convidados - sempre solícitos -, a biblioteca da FMUSP, ao SIBiUSP, a Diretoria da FMUSP e aos membros do DC, alguns verdadeiros amigos, meu sincero muito obrigado.

Menciono ainda, aqui, nominalmente, a equipe da Revista: meu braço direito, Gabriel Berlingieri Polho, editor-executivo; Camila Alves da Silva e Thiago Quadrante Freitas, antiga diretoria que iniciou mudanças no core da RevMed e sempre nos apoiou; João Diego Carmona e Klara Kapronezai Winstanley, diretores sempre solícitos; Robert Zawadzki Pfan, Camila de Oliveira Nuñes, Pablo Rodrigo Andrade da Silva, Isadora Campos de Sousa Abreu, Sara Yumi Motoike, Ricardo de Oliveira Gabriel Souza, Leila Tiemi Okajima, nossos prestativos colaboradores; e Suely Campos Cardoso, secretária executiva, que tornaram realidade avanços significativos para a RevMed.

Agradeço a todos pela oportunidade de poder fazer parte dess história. Levarei comigo essa grande experiência com seus vários momentos sejam de desafios, sejam de satisfação. Conquistei também vários amigos. Desejo, sinceramente, muito sucesso para a futura trajetória desse tão estimado periódico. Tenho a certeza de um futuro brilhante das próximas gestões.

Safisfação imensa, muito obrigado!

\author{
Gustavo Rosa Gameiro \\ Editor-Chefe e Coordenador da \\ Revista de Medicina
}

